\begin{tabular}{|l|l|l|}
\hline \multicolumn{2}{|c|}{ PublisherInfo } \\
\hline \hline PublisherName & $:$ & BioMed Central \\
\hline \hline PublisherLocation & $:$ & London \\
\hline \hline PublisherImprintName & $:$ & BioMed Central \\
\hline \hline
\end{tabular}

\title{
Extended HLA haplotypes and RA susceptibility
}

\begin{tabular}{|c|c|}
\hline \multicolumn{2}{|c|}{ ArticleInfo } \\
\hline ArticleID & 92 \\
\hline ArticleDOI & 10.1186/ar-2001-68101 \\
\hline ArticleCitationID & 68101 \\
\hline ArticleSequenceNumber & 49 \\
\hline ArticleCategory & Paper Report \\
\hline ArticleFirstPage & 1 \\
\hline ArticleLastPage & 4 \\
\hline ArticleHistory & $\begin{array}{ll}\text { RegistrationDate } & : 2001-7-26 \\
\text { Received } & : 2001-3-26 \\
\text { Accepted } & : 2001-7-26 \\
\text { OnlineDate } & : 2001-7-26\end{array}$ \\
\hline ArticleCopyright & Biomed Central Ltd2001 \\
\hline ArticleGrants & \\
\hline
\end{tabular}




\begin{tabular}{|l|l|l|}
\hline ArticleContext & $:$ & 130753311 \\
\hline
\end{tabular}

Derek Mattey, ${ }^{\text {Aff1 }}$

Aff1 Staffordshire Rheumatology Centre, Stoke-on-Trent, UK

\section{Keywords}

Haplotypes, HLA, MIB, microsatellites, rheumatoid arthritis

\section{Context}

Many studies have shown that susceptibility to rheumatoid arthritis (RA) is associated with HLADRB1 alleles which encode similar amino acid sequences (QKRAA, QRRAA or RRRAA) in the third hypervariable region of the HLA-DR ? molecule. This provides the basis for the shared epitope (SE) hypothesis. An alternative RA protection (RAP) hypothesis has been proposed in which susceptibility to RA is conferred by HLA-DQ alleles (DQB1*03-DQA $1 * 03$ and DQB1*0501-DQA1*01) while protection is provided by DRB1 alleles encoding a DERAA motif instead of the SE. Other loci within the MHC may contribute to the linkage of this region with RA susceptibility, and some studies suggest that an extended MHC haplotype predisposes to RA. The aim of this study was to examine the possible contribution of genes other than DQ and DR to the association between HLA and RA.

\section{Significant findings}

The allele distribution of six microsatellites (D6S1014, D6S2673, D6STNFa, MIB, C1-2-5, and C1-3-2) located in the telomeric part of the HLA region was examined in RA patients and controls. Nineteen conserved microsatellite clusters (c1-c19) were identified within the controls. Twelve of these clusters were in linkage disequilibrium with DQB1-DRB1 haplotypes and corresponded to previously described ancestral haplotypes. The $\mathrm{c} 1$ haplotype contained an allele (MIB*350) which was associated with RA when analysed as part of a three point cluster at adjacent loci, i.e. within cluster D6S273*139-D6STNFa*99-MIB*350, D6STNFa*99-MIB*350-C1-2-5*196, or MIB*350-C1-2-5*196-C1-3-2*354. This association with RA at the MIB locus was independent of RApredisposing DQB1-DRB1 haplotypes. The authors conclude that the telomeric part of the HLA region contains a genetic factor which predisposes to RA independently of the HLA class II genes; any locus between that encoding TNF-a and the end of the chromosome could be regarded as a candidate. 


\section{Comments}

This study provides further evidence that genes outside the MHC class II region may contribute to RA susceptibility. The association of the microsatellite cluster $\mathrm{c} 1$ with prediposition to RA is consistent with previous work by Singal and colleagues (see Additional information) who demonstrated an association between the microsatellite D6S273*139 and RA independent of HLA class II. These studies add a further level of complexity to our understanding of the association between RA and the HLA region, and underline the difficulties in identifying the genetic factors responsible. Further large population studies which include more microsatellite loci may help to narrow down the HLA region to the likely gene(s) of interest.

\section{Methods}

Case-control study, PCR, DNA sequencing

\section{Additional information}

Singal DP, Li J, Lei K: D6S273 microsatellite polymorphism and susceptibility to rheumatoid arthritis. Tissue Antigens 1998, 52:353-358 (>a href="http://www.ncbi.nlm.nih.gov/entrez/ query.fcgi? $\mathrm{cmd}=$ Retrieve \&db=PubMed\&list_uids=9820598\&dopt=Abstract" $>$ PubMed abstract $</ \mathrm{a}>$ ).

Singal DP, Li J, Lei K: Genetics of rheumatoid arthritis (RA): Two separate regions in the major histocompatibility complex contributes to susceptibility to RA. Immunol Lett 1999, 69:301-306 (---a href='http://www.ncbi.nlm.nih.gov/entrez/ query.fcgi? $\mathrm{cmd}=$ Retrieve $\& \mathrm{db}=$ PubMed\&list_uids $=10528792 \& \mathrm{dopt}=$ Abstrac' target="---PubMed abstract---/a---).

\section{References}

1. Zanelli E, Jones G, Pascual M, Eerligh P, van der Slik AR, Zwinderman AH, Verduyn W, Schreuder GMT, Roovers E, Breedveld FC, de Vries RRP, Martin J, Giphart MJ: The telomeric part of the HLA region predisposes to rheumatoid arthritis independently of the class II loci. Hum Immunol . 2001, 62: 75-84. 
(C) 2009-2013. SPi Global, Chennai, India. All rights reserved. 